\title{
METHODOLOGY OF PSYCHOLOGY
}

\section{Prerequisites of Sociality: Historical and Evolutionary Analysis}

\author{
Aleksandr G. Asmolov ${ }^{*}$ Eugeniya D. Schekhter, \\ Aleksandr M. Chernorizov, Elena N. Lvova \\ Lomonosov Moscow State University, Moscow, Russia \\ * Corresponding author. E-mail: agas@mail.ru
}

Background. Discussion of the social origins of personality formation, based on the biological individual, is a characteristic feature of modern interdisciplinary researches at the junction of natural science and the humanities. At the same time, evolutionary aspects of the relationship between the biological (innate) and the social (acquired) - i.e., the problem of the origin of sociality - come to the forefront.

Objective. This article presents and discusses the hypothesis that the evolutionary origins of sociality are processes of evolutionary divergence (increasing individual diversity) and convergence (symbiosis) that define two oppositely directed vectors of the development of life from its simplest forms.

Method and Results. The theoretical and experimental data used to discuss the hypothesis are considered here from the standpoint of the historical evolutionary approach to the processes of formation (evolution) of the uniqueness of the personality and of social interpersonal relations. The approach is based on an understanding of these processes as a special case of the evolution of interacting systems on the basis of two opposing trends - towards preserving and towards changing the system. The hypothesis allows us to answer two questions about the ambivalence of human existence in society: (a) Why do all people, regardless of their social status, find it so difficult to endure loneliness, which is incompatible with both the mental and even physical health of each of us? (b) Why at the same time do all of us involuntarily protect the "boundaries" of our own physical, mental, and social "Me", the violation of which is as destructive (unacceptable) to us as is loneliness?

Conclusion. Systematic historical-evolutionary analysis of the sciences of nature, society, and humankind allows us to isolate general patterns of development of complex systems, leading to a more accurate understanding of the phenomenon of personality. Such an interdisciplinary approach was used in this work on the biological roots of sociality and the particular features of individual existence in the external and to some extent social environment that generates unique individuals. 
Keywords: systems, social communities, evolution of societies, sociality, symbiosis, individual diversity, person, historical and evolutionary approach.

\section{Introduction: Problem Statement}

Discussions of the social origin of personality formation based on the "biological individual" is a characteristic feature of modern interdisciplinary research at the junction of natural science and the humanities (Asmolov, 2002; De Waal, 2014; Kandel, 2016; Palmer \& Palmer, 2002; Markov, 2010; Pinker, 1994; Ramachandran, 2006; Ridley, 2014; Wilson, 2015). At the same time, evolutionary aspects of the relationship between the biological (innate) and the social (acquired) - i.e., the problem of "the origin of sociality" - come to the forefront.

In psychology, the correlation of the biological and the social in a person is of special interest (Asmolov, 2002). Different psychological schools propose different solutions to this problem. However, despite the wide range of points of view, all psychological theories (explicitly or implicitly) agree that biological and social processes are interrelated but independent factors in human evolution. The sociogenetic theory of the famous American psychologist A. Gesell (1932) is a classic example.

At the same time, it is possible that the phenomenon of sociality itself (but not its form) is a product of biological evolution and that its roots are closely associated with the phenomenon of symbiosis - the mutually beneficial coexistence of genetically diverse organisms. In other words, as a product of evolution, sociality may be deeply rooted in human biological nature, and it is one of necessary conditions of life not only as a personality (a social being) but also as an individual (a biological being).

Sociobiology was established as a separate field of knowledge by Edward Wilson - an American biologist, author of the fundamental work Sociobiology: The new synthesis, in which sociobiology is defined as the systematic study of the biological foundations of the social behavior of all types of organisms, including humans (Wilson, 1975, 2015). As a result of systemic (sociobiological) processes, social relations are characterized by their specific features and variety of forms. The specificity of social relations is determined by the fact that a necessary condition of sociality is communication between unique personalities (Luhman, 1995), with an obligatory combination of similarities and differences between their meaning spaces, since complete similarity makes interaction meaningless and absolute difference makes it impossible (Lotman, 2015).

This article presents and discusses the hypothesis that the evolutionary origins of sociality are processes of evolutionary divergence (increasing individual diversity) and convergence (symbiosis) that define two oppositely directed vectors of the development of life from its simplest forms. The theoretical and experimental data used to discuss the hypothesis are considered here from the standpoint of the historical evolutionary approach to the processes of formation (evolution) of the uniqueness of the personality and of social interpersonal relations. The approach is based on an understanding of these processes as a special case of the evolution of interacting systems on the basis of two opposing trends - towards preserving and towards changing the system (Asmolov, 1986, 1996, 2002, 2007, 2008, 2012, 
2013). Analysis of the embodiment and meaning of these trends in the activity of the organism, the brain, and the psyche, of their contribution to personal diversity, is a continuation of the research program "Historical and evolutionary synthesis: Paradigm of diversity development in biological, social and mental systems" (Asmolov, Schekhter, \& Chernorizov, 2013), which is being developed based on the Russian scientific schools founded by A.N. Severzev and I.I. Schmalgauzen; L.S. Vygotsky, A.N. Leontiev, and A.R. Luria; A.A. Ukhtomsky, N.A. Bernstein, and E.N. Sokolov (Asmolov, 2013; Asmolov et al., 2013; Asmolov, Schekhter, \& Chernorizov, 2014; Asmolov, Schekhter, \& Chernorizov, 2016; Chernorizov, Asmolov, \& Schechter, 2015).

The hypothesis allows us to answer two questions about the ambivalence of human existence in society: (a) Why do all people, regardless of their social status, find it so difficult to endure loneliness, which is incompatible with both the mental and even physical health of each of us? (b) Why at the same time do all of us involuntarily protect the "boundaries" of our own physical, mental, and social "Me", the violation of which is as destructive (unacceptable) to us as is loneliness?

\section{Man Is a Social Animal}

"Man is a social animal". This statement by Aristotle, referenced in the title of a book by American social psychologist Elliot Aronson, means that everyone strives to live in community with other people (Aronson, 1998). This "predisposition" to social contact is not exclusive to humans, because cooperative existence is a universal way of life for all living beings, regardless of their level of development. This idea was postulated in the nineteenth century by French philosopher and sociologist Alfred Espinas (2016). Later it was illustrated by P. Kropotkin (2007) and by modern researchers with an analysis of the facts of cooperation that are characteristic of different species, from invertebrates to humans (Grechenko et al., 2014, 2015).

Symbiosis - i.e., mutually beneficial coexistence - is a feature of life from the very beginning, starting from its basic, bacterial, forms that created conditions for the circulation of substances on the Earth through the interactions of various types of protozoa. The great Russian microbiologist and evolutionist G.A. Zavarzin (1993) has formulated a rule according to which energy cycles' insularity, which determines biospheric stability, can only be achieved by a community of several different types of microorganisms that share biogeochemical functions. It is Zavarzin to whom belongs the phrase, shocking at first glance, "In the beginning was the community" (cited by Markov, 2010, p. 86). The meaning of the phrase is that life is impossible outside of communities of diverse organisms. Microorganisms are important for the origin and evolution of social life for the following reasons. As the base of the trophic pyramid, they largely determined the fate of all other organisms that "fit" into the already formed bacterial biosphere, as their habitat (Zavarzin, 2003). Moreover, bacteria are largely responsible for not only the existence but also the lines of development of all other organisms, because each evolutionary stage follows from the previous one, and the overall direction of the process from initial forms of life to humans is an expression of life's common strategy. This conclusion (though with caution and a disclaimer about the limitations of our knowledge) 
was drawn by Clifford Grobstein, a well-known American biologist who considered the variety and consistently increasing complexity of the organization of living things as the natural path of progress (Grobstein, 1968). Grobstein was supported by the leading geochemist E.M. Galimov (a disciple of A.I. Oparin), who wrote that "nature prefers to adapt already existing structural and functional possibilities to neoformations, rather than to take a path again or to turn to alternative solutions" (Galimov, 2001, p. 70).

If the coexistence of individuals has the force of an immutable biological law, then in relation to the evolution of various species (primarily the biogenesis and anthrosociogenesis of Homo sapiens), we can delineate three rules of the evolution of "social nature":

1. Human individuality, as one of the phenomena of the progressive evolution of living systems, is generated and transformed in the "flow of activities" with other people.

2. "The flow of activities" acts as the driving force of the historical-evolutionary process and causes the generation of diverse living systems through different but concurrently implemented forms of selection (a directing selection, a stabilizing selection, a disruptive selection, a balancing selection).

3. The unit of development of the individual, of personality and individuality, is a "co-action" with other people, a phenomenon of symbiotic evolution. It should be particularly noted that the idea of "co-action" as a unit of human species development was most clearly formulated by P.A. Kropotkin in his consideration of mutual aid in the world of people and animals, as a factor of evolution. In the context of developmental psychology, the hypothesis of "co-action" as the unit of the individual development of a child and as a special unit of socialization was developed by the classic author of Russian child psychology A.V. Zaporozhets, who was a student and follower of L.S. Vygotsky (Asmolov, 2007; Zaporozhets, 1986).

So, individuality is formed in social interactions. As it was figuratively expressed by the famous researcher of primate behavior Robert Yerkes, "One chimpanzee is not a chimpanzee at all” (cited by Lorenz, 1998, p. 198). To an even greater extent this can be applied to humans. For psychologists, this truth has become trivial, but because of its importance, it is also emphasized in psychological research. For example, here is the statement of S. Averintsev, a famous cultural historian and philosopher, whose contribution to the rapprochement of nations and cultures received worldwide recognition: "No writer can become himself, he can't become at all, without somehow distancing himself from his 'neighborhood' " (Averintsev, 2004, p. 227).

Each of us aspires from birth to communicate with others. This need often exceeds that for food and warmth. A newborn baby's first "meaningful" smile is always a social smile, and the natural stimulus is visual contact with another person; however, the motor functions of the smile are innate, as it is stereotypical and appears spontaneously on the face of not only sighted infants, but also of the blind, during the first hours of life. Thus, it can be stated the social smile, which facilitates the formation of connections between people, has an innate basis (Izard, 2011). 
This, in turn, is evidence that the predisposition to cooperative existence is genetically determined and a species-specific human characteristic.

It is possible to illustrate the genetic predisposition to a social way of life by starting from its opposite, namely by analysis of the selective loss of this predisposition with certain pathologies. An example is autism (from the Greek word autos - "self") - a morbid state that results in avoiding social contact and in unnatural self-absorption. Symptoms of this disorder were described and singled out as a syndrome independently by two researchers, Leo Kanner (1943) and Hans Asperger (1944). Asperger gave it the name "autistic psychopathy". One of its forms was called "early" or "classic" autism (Kanner, 1943). The word "early" refers to its appearance in newborns and particularly in children under six years of age. People with a severe form of classic autism do not react to the human face; in infancy they do not reach for the mother; in the first years of life they hardly ever enter into interaction and do not like being touched or held. They look "through" people or walk past them as if they do not see them. At the age of three to five, these children often remain silent for very long periods, and if they occasionally speak to someone, they look away. Not being interested in other people and avoiding them, they prefer inanimate objects and have a poor understanding of the emotional state of others (Nikolskaya, 2000) and of spoken language (Ferrari, 2006).

Impairment in autism is selective: The ability to grasp the meaning of speech and to use it for communicative purposes is lost, without affecting the subject's perceptual domain. Indeed, numerous studies of autism, which can be considered as a model of social disadaptation, suggest that the precondition for socialization is an independent psychophysiological function (Bettelheim, 2004; Lebedinskiy, 1985; Wing, 1981) of an organic nature (Coleman \& Gillberg, 1985; Sirota et al., 2011; Steffenburg, 1991).

Full realization of the preconditions for socialization requires not only a genetic predisposition, but also the experience of communication with other people at early (sensitive) ontogenetic periods, when a general law is observed that is valid for all quantitative traits: Genotype functioning is determined by its interaction with the external environment in which development takes place ${ }^{1}$ (Davidenkov, 1947). Thus, at least in the case of socialization, the question of "What comes first, the chicken (environment) or the egg (heredity)?" is not relevant, because a positive result requires both. Therefore, a child's lack of contact with parents or close interaction with other people, especially when the child is under the age of three, as well as impairment of the predisposition for socialization, leads to irreversible mental and behavioral disorders (Fries et al., 2005). These disorders are so characteristic that they were given the name "hospital syndrome", the symptoms of which are a yearning face, a pose "against the wall", and/or monotonous, repetitive rocking.

Chronic loneliness is disastrous not only in childhood. Lack of social support causes severe stress in adults, disrupting their brains as well as the immune and

1 Inherited characteristics are divided into two categories. The first includes characteristics defined by a limited number of genes that are inaccessible to environmental influence; they are manifested in a discrete form and correspond to Mendel's laws (inherited disease is an example). The second category - quantitative characteristics - are polygenic; they are always influenced by environment, are manifested not discretely, but with continuous values. Mendel's laws are not applicable (Davidenkov, 1947). 
biochemical status of the organism as a whole (Cacioppo \& Patrick, 2008). The consequences are low resistance to illnesses, emotional disorders, and general lethargy (hypodynamia) with elements of abulia (Adolphs, 2009, 2010; Aleksandrovskiy, 1996).

\section{Individuality in Community}

So, each of us has a predisposition to socialization, including the desire to live with other people. But why is the constant presence of even those closest to us, especially uninvited interference in our internal world, so hard to endure? Where does the force of involuntary "repulsion" come, which limits our accessibility to others?

To understand the origin of the need to preserve "individual distance", we can compare human society with other biological communities, in which some individuals with an irresistible herd mentality do not distance themselves from each other. For example, inside the hive, bees feel comfortable just from physically feeling each other (Fabre, 2005). Fishes also have no fear of touching one another, although the school of fish forms a dense mass. The same is observed in giant families of rats, in which the animals are always ready for close contact and are always friendly to members of their family (Lorenz, 2003). What is characteristic of such associations? Firstly, it is high degree of genetic similarity (all members are related by kinship), and in this regard the associations resemble genetically equipotential individual organs of a single organism. Like an organism, units of such communities are significant insofar as their function satisfies the interests of the system as a whole (Asmolov et al., 2016; Dawkins, 1993). Personality is neutralized, and the animals recognize each other on the basis of a characteristic that is common to all members of the association - the "friend or foe" principle. Therefore, communities of this type are called "anonymous" (Lorenz, 1998; Zorina et al., 1999).

An "anonymous" shoal, flock, or herd is a mode of existence of fish, birds, and herd animals, which is common for certain periods of life. An extreme expression of anonymity in the human world is a crowd that acts as a kind of monolithic whole. In social psychology, this phenomenon is explained by the special situation of a person in a crowd when he temporarily loses the psychological traits that characterize him as a unique individual. This situational disappearance of the conscious personality is called depersonalization. It is more probable when the crowd is anonymous, and excitement associated with emotional contagion is high (Lebon, 1998). But still, for humans such behavior is not typical and is a (temporary) manifestation of evolutionary regression.

Compared to anonymous animal communities, a highly developed human community is always personalized and is characterized by the combination of the individual uniqueness of all its members, with their capacity for interpersonal relations based on interactions of "asymmetric meaning spaces" (Lotman, 2015).

These characteristics have biological origins. The universal significance of the differences among the elements that form a living system of any level of complexity was assessed by Gregory Bateson, an outstanding theorist of systems who made significant contributions to anthropology, psychiatry, and communications theory. He came to the conclusion that "integrities" are created only by the interaction of differentiated "parts" (Bateson, 2007). Social systems are subjected to this general law, 
the fulfillment of which is guaranteed by biological mechanisms specifically aimed at maintaining individual diversity. Let us recall some of them.

Sexual reproduction is the starting apparatus that systematically "works" on the uniqueness of the members of the community; it is an evolutionarily advantageous acquisition of multicellular organisms. It allows genome changes to happen not from time to time (as in mutations and horizontal gene transfer), but inevitably in the life of each individual. The effect is achieved by the interaction of two partners who are divergent by a set of different properties ${ }^{1}$, and whose descendants inherit not exact copies of the parental genomes, but a mixture of them. The randomness of the combinations is of fundamental significance, because it makes the number of genetic combinations almost unlimited, and so individuals never duplicate each other exactly. The essence of this phenomenon is that randomness is a law, guaranteeing individual uniqueness. And it is uniqueness that defines the unconditional evolutionary success of sexual reproduction, because polymorphic populations cope better with the environment and more successfully avoid catastrophe (Altukhov, 2003; Grobstein, 1968).

But the matter is not limited to the initially (genetically) given diversity of organisms: Personal life experience is added to that and transforms the conceptual world of the individual, because the individual's conceptual world is a point of growth of our species. Development of conceptual world moves social interactions to a depth that is characteristic only of human beings (Asmolov, 2008). In other words, personification is associated not with diversity in general, but with dominance of the variability of personal meaning spaces in which the environment plays a primary role. However, the genome also contributes here, as it forms the anthropological prerequisite for the development of human individuality. Let's further analyze this statement.

The characteristic of individual features associated with brain activity is their incomplete genetic determination. In the development in a social community, the hereditary basis of these features manifests itself not in the original form, but in a form corrected by experience, because it is always "fitted" to specific conditions of existence $^{2}$ (Davidenkov, 1947). For example, the physiologically determined ability to experience pleasure is inherent in all people from birth, but our preferences in relation to sources of pleasure depend on how this precondition affects the choice of a particular activity in the life of an individual.

Individual inclinations are dynamic because of the unprecedented plasticity of the human brain, its ability to rebuild its structure and function in accordance with changing environmental conditions. But the predisposition itself is genetically specified. It is implemented with regulatory gene complexes and with informationneutral so-called "meaningless" nucleotide sequences (the analogs of individual

1 For some primitive multicellular organisms, the differentiated germ cells coexisting within one body can participate in pairing. But with an increase in development, sex differences become more substantial. In humans, sexual differentiation is characterized by divergence of: (a) chromosomal difference between sexes; (b) difference at the level of organs responsible for production of germ cells; (c) difference at the level of secondary sexual characteristics; (d) psychological differences between the sexes; (e) differences in the social roles of heterosexual individuals. Only levels a, b, and c are strictly determined biologically (Gilbert, 1995).

2 With the exception of hereditary diseases. 
letters in a text), the activation of which (under certain conditions) can provide unlimited possibilities for creating new genetic programs and for increasing the complexity of existing ones, without a significant increase in the size of the genomes (Golubovskiy, 1985; Klug \& Cummings, 2009). The genetic predisposition of the brain to form multiple functional modes substantially extends its information potential, which reaches its maximum in humans (Allis, Jenuwein, \& Reinberg, 2013). Thus, to acquire a highly individual experience, an even greater genetic apparatus is required than for inherited forms of behavior. The results of lifetime changes due to brain plascticity are not transmitted to offspring, because they take place not in reproductive cells, but mainly in nerve cells (Anokhin, 1968). But precisely because of this plasticity, everyone is able to assimilate a specific environment through his own experience, including cultural experience, which determines the originality of his personality.

The uniqueness of each person is not accidental: It is a result of the evolutionary process, demonstrating the ascent of life to greater diversity (Asmolov, 2012). The expediency of this pattern is determined by the relationship between the genetic diversity of a population and its adaptability. This relationship was formalized by the outstanding mathematician and geneticist Ronald Fisher in a famous theorem which is often called "the fundamental theorem of natural selection" (Fisher, 2011): "The rate of increase in fitness of any organism at any time is equal to its genetic variance in fitness at that time". In other words, with growth in the variety of individuals that form a population, the range of influences to which the whole population is adapted expands. Thus, the uniqueness of each person is an important driving factor of evolution and is subject to pressure from natural selection, as the viability of the community as a whole depends on the diversity of its individuals. To avoid degeneration, we have to be different.

So, we emphasize the following. The biological nature of the human individual is distinguished by initial (inborn) genetic uniqueness, but the most significant contribution to the inexhaustible variety of people is made by personal life experience. However, the ability to change during the course of life also has genetic preconditions. Thus, the essence of the human personality is not compatible with uniformity (monotony). Nature "stands" here on the side of each person's identity.

Individual uniqueness is a necessary but not sufficient condition for the personification of society. Another necessary requirement is the attitude to other people as independent persons who have not only their own external appearance, but also their unique inner world, a priori different from our own. This is the source of our being equipped with mechanisms of "social cognition", which become more specialized during evolution, while becoming gradually separated from other information streams. Specialized mechanisms of social perception are the source of knowledge about "the Other" (Andreeva, 2000; Chernorizov et al., 2015).

After language, the most important means of social contact is the face; therefore, it is not surprising that facial recognition has a specialized brain module, located in the temporal-occipital region (Chernorizov, Zong-qing, Petrakova, \& Zinchenko, 2016; De Renzi, 1997). Damage to this region leads to the inability to recognize faces - facial agnosia (prosopagnosia) - which can be selective, not accompanied by loss of other mental functions. Described in the mid-nineteenth 
century, this pathology is well known today to a wide audience, thanks to the popular book by Oliver Sacks, The Man Who Mistook His Wife for a Hat (Sacks, 1985).

Face perception allows us not only to identify partners in dialogue, but also opens up access to their inner world, as facial expression is one of the most visible and easily distinguishable expressions of a subject's emotional state. However, facial expression has a special place among things with a similar function (notably vocal intonation, posture, gestures), because the relationship between basic emotions and the corresponding patterns of activity of the facial muscles is specified a priori and is universal in all people (Bruce \& Young, 2012; Ekman \& Frisen, 1978).

In accordance with different tasks - perceptual and conceptual - within the "facial" brain region, there is a subtle specialization of cells, some of which are focused on face recognition, while others are focused on different facial expressions transmitting emotional state in symbolic form (patterns of facial muscle activity) (Perrett, Rolls, \& Caan, 1982). Such specialization is consistent with clinical observations according to which the loss of ability to recognize certain faces does not prevent patients from adequately perceiving emotional expressions, but they do so impersonally, i.e., as "someone is sad", "someone is happy", "someone is surprised". The inverse also holds: The ability to "read" emotional facial expressions can be lost selectively (Eirner \& McCarthy, 1999). Such separation of functions corresponds to the general strategy of the brain, according to which perceptual (identification) and conceptual (interpretation) information channels are neurophysiologically independent (Izmailov, Korshunova, \& Sokolov, 2003; Sokolov, 2010).

Face detectors ("gnostic neurons") are part of a specific cortical visual system of the human brain, integrating information about the stationary and dynamic properties of objects in the external environment - the so-called "Who? System" (Kanwisher \& Dilks, 2013). In this system there are two functionally and anatomically distinct areas associated separately with the analysis of information about living organisms and nonliving objects. Such separation of brain functions (in relation to living and nonliving systems) relates to the increasing role of social interactions in communities that are becoming increasingly complex during the course of evolution. Whereas, according to comparative anatomy, the first evolutionary stages of brain development relate to improvement of sensory systems (focus on identification of external environment objects), in the later evolutionary stages, brain development begins to be influenced by sociocultural factors (Adolphs, 2009, 2010; Chernorizov et al., 2015, 2016; Falikman \& Cole, 2014). Animals are able to evaluate (identify) each other solely by their appearance, the effectiveness of their actions, and the externally expressed readiness to perform actions. Only humans show not only narrow and practical interest in an interlocutor, but also accentuated attention to the inner content of that individual's personality, the uniqueness of which is valuable in itself, regardless of its utilitarian usage (Buber, 1995; Von Hildebrandt, 1998). We not only cognize the personality of the "Other"; we "feel" it. And the first step in this direction is interpretation of the Other's emotional state through a "reading" of external symbols (speech, posture, gestures, facial expressions).

Thus, humans have innate predispositions, which, as these evolve, make it possible to precisely judge the psychological state of another person and to distinguish 
it from their own. Such estimation is a necessary foundation for any individual personalized communication, but this communication is productive only when both sides agree that the mental world of the "Other" is unique and therefore equivalent to one's own. The ability to recognize individual identity and the equality of the "Other" is a manifestation of culture, which indicates a high level of social development of civilization.

Existence in a personified community is inevitably ambivalent - necessarily together, but with obligatory acceptance of the identify of each "Me". This predetermined contradiction leads to a combination of prosocial behavioral forms with the mechanisms of protection of each "Me" from infringement by other community members.

Protective mechanisms have their own evolutionary history and become more sophisticated and subtle as a characteristic of individuality becomes not only physically, but also mentally, distinctive. Animals also have a rudimentary "I", which includes their own bodies, their own territories, and sometimes their close relatives (carriers of common genes). The instinctive need to preserve all of this manifests itself in an innate "freedom reflex", a term introduced by I.P. Pavlov. Some of the dogs he observed were unable to develop new skills because of strong excitation: They were constantly straining against the leash, because they absolutely could not stand captivity (Pavlov, 1951). Both in animals and in human populations, the need for freedom is represented quantitatively, i.e., by the entire set of values that range from complete intolerance of any violence to a propensity to complete submission. According to the law of normal distribution of quantitative traits, extremes are rare. Most people have an instinctive desire for freedom, expressed to a medium degree (Hedrick, 2003).

Violation of the desire for freedom is always accompanied by a strong experience - anger, which is one of the basic human emotions. Physical limitation is the universal, genetically programmed, activator of this emotion. In newborns, anger, clearly expressed in facial expressions, occurs when an adult restricts the movement of the child's hands. As the person matures and his mental "I" develops, physical limitation ceases to be the sole cause of anger. Older children, especially teenagers, react to psychological restrictions even more intensively than to physical ones. The main causes of anger among adults are actions imposed by other people and committed against their will, and the feeling of being treated unfairly, being betrayed, or used.

The biological significance of anger that accompanies an assault on the "Me" is that it mobilizes the energy the person needs for self-defense. Subjectively it is experienced as a sense of confidence and strength, and it creates a readiness for action. But the action may be of different sorts. The most primitive, literally "animal" way of protecting oneself is an aggressive action. It can be called "animal" because healthy, socially useful aggressiveness of animals and humans has a common evolutionary basis. It is rooted in the territoriality that is inherent to animals and the need to maintain individual distance (Lorenz, 1998; Rizzolatti \& Sinigaglia, 2012). The measure of individual distance is the distance between individuals at which the probabilities that they will tolerate or attack each other are equal. Territoriality is partially preserved in humans. The proof of this is, for example, the involuntary irritation we feel in a tightly packed queue, or the discomfort of not having "a place of our own". 
Having common evolutionary roots, the aggressiveness of animals and humans also has a common evolutionary meaning, which consists of the need to resist infringement by other individuals or communities. Proof of the fact that aggression serves individuality, is that individuals in anonymous communities are not aggressive (Lorenz, 1998, 2003).

Aggression needs to be limited, since it is potentially dangerous due to the tendency to transition into socially unacceptable forms. It is like a poison that heals in microdoses, but kills in larger quantities. Therefore, not only culture, but nature itself has provided means to limit aggression. One of these is fear. The sensitivity of aggression and fear to the same biochemical agents shows them to be genetically related. In particular, the injection of cholecystokinin protein simultaneously provokes fear and conflict behavior (Ashmarin, 1999).

Fortunately, aggression is not the only way to preserve our individual "Me". Another method of self-expression and self-reward is creative activity. Germs of creativity are observed in chimpanzees. When the apes were given sheets of blank paper and a set of paints and brushes and allowed to do whatever they wanted, each of them, with great effort, made unique pictures. Characteristically, all attempts to stimulate the apes to imitate drawings of others were unsuccessful. The only condition of creative activity in this case was self-reward. In order to test this, the researchers tried to bribe one of the chimpanzees with food. The ape quickly learned to associate drawing with getting the reward, but once that connection was made, the animal became less and less interested in the drawings. The chimp drew a couple of strokes and then immediately reached for a handout (Morris, 1962).

Not only artistic creation, but also perception of it, is an active expression of individuality. Joseph Brodsky wrote: "Aesthetic choice is always individual, and aesthetic experience is always private experience. Every aesthetic reality makes the person who experiences it more private, and this privacy, taking sometimes the form of literary (or some other) taste, can be if not a guarantee, then a form of defense against enslavement" (Brodsky, 1998, p. 9).

Unlike aggression, creativity is not a biologically regulated means of protecting the "Me" because, being originally a personal matter, it contributes to the development of both the creator and social reality. To explain this, it is necessary to clarify the difference between the physical space and the meaning space of the human individual.

By definition, personal meaning is an individualized reflection of reality, expressing a person's relation to the objects to which he directs his activity and communication. The system of personal meanings is a "deep" characteristic of each individual (Asmolov, 2007). Due to the uniqueness of each individual, personal meaning spaces are "asymmetrical", i.e., they always include areas that do not have one-to-one correspondence with those of other people. Completely non-overlapping personal meaning spaces, like constants of the human body, are discrete, and thus separated by boundaries. However, unlike physical boundaries that preserve the balance of a physiological system, a person's conceptual boundaries are not limited and are "an eternally unfinished painting", constantly being transformed under the influence of the meaning spaces of "Others". This flexibility is conducive to general improvement of knowledge and forms a reserve for social development, because it is at an open boundary that new meanings are produced, in the compet- 
ing semiotic interaction of asymmetric structures (Lotman, 2015). Thus, in contrast to a physical boundary, a conceptual boundary is always moving and is a region of generation of new (social) knowledge. But novelty is what prevents stagnation and promotes development of both the individual and his environment (Asmolov et al., 2014; Schrödinger, 2005).

\section{Conclusion}

In psychology and pedagogy it is often said that people are formed by conditions of life and upbringing. While agreeing with this in principle, we specify only that despite the priority of life experience, the influence of socio-cultural factors is not a monopoly. In searching for additional roots of personality, we must take a closer look at the natural foundation that is connected with the often hidden but natural biological context of human social existence.

Systematic historical-evolutionary analysis of the sciences of nature, society, and humankind allows us to isolate general patterns of development of complex systems, leading to a more accurate understanding of the phenomenon of personality. Such an interdisciplinary approach was used in this work on the biological roots of sociality and the particular features of individual existence in the external and to some extent social environment that generates unique individuals. If one goes back to the beginning of this article and repeats the question about the origins of the contradictory nature of human mutual "attraction" and mutual "repulsion", we have to admit that the ambivalence of their co-existence is deeply rooted in the properties of living matter, because only non-identical organisms come together, striving for self-preservation.

\section{Acknowledgements}

The research was supported by Grant 16-06-00764 from the Russian Humanitarian Scientific Fund (RGNF). The authors acknowledge partial support from the M.V. Lomonosov Moscow State University Program of University Development to 2020.

\section{References}

Adolphs, R. (2009). The social brain: Neural basis of social knowledge. Annual Review of Psychology, 60, 693-716. https://doi.org/10.1146/60110707163514

Adolphs, R. (2010). Conceptual challenges and directions for social neuroscience. Neuron, 65(6), 752-767. https://doi.org/10.1016/201003006

Aleksandrovskiy, Yu.A. (1996). Sotsialno-stressovye rasstroystva [Socio-stress disorders]. Russkiy meditsinskiy zhurnal, 3 (11), 689-694. Retrieved from http://www.medlit.ru/journal/615

Allis, C.D., Jenuwein, T., \& Reinberg, D. (Eds.) (2013). Epigenetika [Epigenetics]. Moscow: Tekhnosfera.

Altukhov, Yu.P. (2003). Geneticheskie protsessy v populyatsiyakh [Genetic processes in populations]. Moscow: IKTS Akademkniga.

Andreeva, G.M. (2000). Psikhologiya sotsialnogo poznaniya [Psychology of social cognition]. Moscow: Aspekt Press.

Anokhin, P.K. (1968). Biologiya i neyrofiziologiya uslovnogo refleksa [Biology and neurophysiology of the conditional reflex]. Moscow: Nauka. 
Aronson, E. (1998). Obshchestvennoe zhivotnoe. Vvedenie v sotsialnuyu psikhologiyu [The social animal. Introduction to social psychology]. Moscow: Aspekt Press.

Ashmarin, I.P. (Ed.) (1999). Biokhimiya mozga [Biochemistry of the brain]. Saint Petersburg: $\mathrm{SPb}$. University.

Asmolov, A.G. (1986). Istoriko-evolyutsionnyy podkhod k ponimaniyu lichnosti: problemy i perspektivy issledovaniya [Historical and evolutionary approach to understanding personality: Problems and prospects of research]. Voprosy psikhologii, 1, 28-40. Retrieved from http://www.voppsy.ru/eng/news.htm

Asmolov, A.G. (1996). Kulturno-istoricheskaya psikhologiya i konstruirovanie mirov [Culturalhistorical psychology and the construction of worlds]. Moscow: Institut prakticheskoy psikhologii. Voronezh: NPO MO-DEK.

Asmolov, A.G. (2002). Psikhologiya lichnosti: prinzipy obshchepsikhologicheskogo analiza [The psychology of personality: Principles of general psychological analysis]. Moscow: Smysl; Akademiya.

Asmolov, A.G. (2007). Psikhologiya lichnosti. Kulturno-istoricheskoe ponimanie cheloveka [Psychology of personality. The cultural-historical understanding of humans]. Moscow: Smysl; Izdat. Tsentr Akademiya.

Asmolov, A.G. (2008). Istoriko-evolyutsionnaya paradigm konstruirovaniya raznoobraziya mirov: deyatelnost kak sushchestvovanie [The historical-evolutionary paradigm of designing a diversity of worlds: activity as existence]. Voprosy psikhologii, 5, 3-11. Retrieved from http://www.voppsy.ru/eng/news.htm.

Asmolov, A.G. (2012). Optika prosveshcheniya: sotsiokulturnye perspektivy [Optics of education: sociocultural perspectives]. Moscow: Prosveshchenie.

Asmolov, A.G. (2013). Psikhologiya v psikhozoyskuyu eru: ot analiza evolyutsii psikhiki - k analizu psikhiki kak "dvizhitelya" evolyutsii [Psychology in the psychozoic era: from analysis of the evolution of mind toanalysis of the psyche as a "mover" of evolution]. Natsionalnyy psikhologicheskiy zhurnal, 1 (9), 1-4. Retrieved from http://npsyj.ru/articles/detail. php? article $=2487$

Asmolov, A.G., Schekhter, E.D., \& Chernorizov, A.M. (2013). Istoriko-evolyutsionnyy sintez: vzaimnaya pomoshch kak factor evolyutsii [Historical-evolutionary synthesis: Mutual aid as a factor in evolution]. Voprosy psikhologii, 6, 1-12. Retrieved from http://www.voppsy.ru/ eng/news.htm.

Asmolov, A.G., Shekhter, E.D., \& Chernorizov, A.M. (2014). Po tu storonu gomeostaza: istorikoevolyutsionnyy podkhod k razvitiyu slozhnykh system [Beyond homeostasis: The historical and evolutionary approach to the development of complex systems]. Voprosy psikhologii, 4, 3-15. Retrieved from http://www.voppsy.ru/eng/news.htm.

Asmolov, A.G., Schekhter, E.D., \& Chernorizov, A.M. (2016). Ot organizma kak tselogo k personifitsirovannomu soobshchestvu: transformatsiya samoorganizatsii v sociobiologii [From the organism as a whole to a personalized community: A transformation of self-organization in sociobiology]. Psikhologicheskie issledovaniya, 9 (48), 2-8. Retrieved from http:// psystudy.ru.

Asperger, H. (1944). Die autistischen Psychopathen. Kindesalter. Archiv für Psychiatrie und Nervenkrankheiten, 117, 76-136. https://doi.org/10.1007/BF01837709

Averintsev, S.S. (2004). Obraz antichnosti [The image of antiquity]. Saint Petersburg: Azbukaklassika.

Bateson, G. (2007). Razum i priroda: neizbezhnoe edinstvo [Mind and nature: A necessary unity]. Moscow: KomKniga.

Bettelheim, B. (2004). Pustaya krepost. Detskiy autism i rozhdenie "Ya" [The empty fortress. Infantile autism and the birth of the self]. Moscow: Akademicheskiy Proekt: Traditsiya. 
Brodsky, I. (1998). Sochineniya Iosifa Brodskogo [The Works of J. Brodsky]. Vol. I. Second edition. Saint Petersburg: Pushkinskiy Fond.

Bruce, V., \& Young, A. (2012). Face perception. London: Psychology Press.

Buber, M. (1995). Dva obraza very [Two images of faith]. Moscow: Respublika.

Cacioppo, J.T., \& Patrick, W. (2008). Loneliness: Human nature and the need for social connection. New York: W.W. Norton \& Company.

Calder, A., Johnson, M., \& Haxby, J. (Eds.) Oxford handbook of face perception (pp. 114-129). New York: Oxford University Press.

Coleman, M., \& Gillberg, C. (1985). The biology of the autistic syndromes. New York: Praeger.

Chernorizov, A.M., Asmolov, A.G., \& Schechter, E.D. (2015). From physiological psychology to psychological physiology: Postnonclassical approach to ethnocultural phenomena. Psychology in Russia: State of the Art, 8 (4), 4-22. https://doi.org/10.11621/pir.2015.0401

Chernorizov, A.M., Zhong-qing, J., Petrakova, A.V., \& Zinchenko, Yu.P. (2016). Face cognition in humans: Psychophysiological, developmental, and cross-cultural aspects. Psychology in Russia: State of the Art, 9 (4), 37-50. https://doi.org/10.11621/pir.2016.0404

Davidenkov, S.N. (1947). Evolyutsionno-geneticheskie problemy v nevropatologii [Evolutionarygenetic problems in neuropathology]. Leningrad: Tip. im. Volodarskogo.

Dawkins, R. (1993). Egoistichnyy gen [The selfish gene]. Moscow: Mir.

De Renzi, E. (1997). Prosopagnosia. In T.E. Feinberg \& M.J. Farah (Eds.), Behavioral neurology and neuropsychology (pp. 245-255). McGraw-Hill, New York.

De Waal, F. (2014). Istoki morali. V poiskakh chelovecheskogo u primatov [The bonovo and the atheist. In search of humanism among the primates]. Moscow: Alpina non-fikshn.

Eirner, M., \& McCarthy, R.A. (1999). Prosopagnosia and structural encoding of faces: Evidence from event-related potentials. NeuroReport, 10, 255-259. https://doi.org/10.1097/ WNR.0000000000000876.

Ekman, P., \& Friesen, W. (1978). Facial Action Coding System. A technique for the measurement of facial movement (pp. 15-20). Consulting Psychologists Press, Inc.

Espinas, A. (2016). Sotsialnaya zhizn zhivotnykh [The social life of animals]. Moscow: URSS.

Fabre, J.H. (2005). Zhizn nasekomykh [The life of insects]. Moscow: e-book.

Falikman, M.B., \& Cole, M. (2014). Kul'turnaya revolyutsiya v kognitivnoy nauke: ot neyronnoy plastichnosti do geneticheskih mekhanizmov priobreteniya kul'turnogo opyta [Cultural revolution in cognitive science: From neuroplasticity to genetic mechanisms of accumulation of cultural experience]. Kulturno-istoricheskaya psikhologiya, 3, 4-18. Retrived from http://psyjournals.ru/en/kip/2014/n3/75430.shtml.

Ferrari, P. (2006). Detskiy autism [Childhood autism]. Moscow: ROO Obrazovanie i zdorovie.

Fisher, R. (2011). Geneticheskaya teoriya estestvennogo otbora [The genetical theory of natural selection]. Moscow: Institut komyuternykh issledovaniy, Regulyarnaya i khaoticheskaya dinamika.

Fries, A.B.W., Ziegler, T.E., Kurian, J.R., Jacoris, S., \& Pollak, S.D. (2005). Early experience in humans is associated with changes in neuropeptides critical for regulating social behavior. PNAS, 102 (47), 17237-17240. https://doi.org/10.1073/pnas.0504767102

Galimov, E.M. (2006). Fenomen zhizni: mezhdu ravnovesiem i nelineynost'yu. Proiskhozhdenie i prinzipy evolyutsii [The phenomenon of life: Between equilibrium and nonlinearity. The origin and principles of evolution]. Moscow: Editorial URSS.

Gezell, A. (1932). Pedologiya rannego vozrasta [Pedology of early childhood]. MoscowLeningrad: UCHGIZ.

Gilbert, S. (1995). Biologiya razvitiya [Biology of development]. Vol. 3. Moscow: Mir.

Golubovskiy, M.D. (2013). Organizatsiya genotipa i formy nasledstvennoy izmenchivosti eukariot [Genotype organization and forms of eukaryotes' genetic variation]. Vavilovskiy zhurnal genetiki i selektsii, 17 (4/2), 805-832 
Grechenko, T.N., Zhegallo, A.V., \& Kharitonov, A.N. (2014). Kommunikatsii prokariot [Communications among prokaryotes]. In Estestvenno-nauchnyy podkhod $v$ sovremennoy psikhologii (pp. 246-258). Moscow: IP RAN.

Grechenko, T.N., Kharitonov, A.N., Zhegallo, A.V., \& Aleksandrov, Yu.I. (2015). Psikhofiziologicheskiy analiz ostsillyatornykh protsessov $\mathrm{v}$ povedenii biosotsialnykh sistem [Psychophysiological analysis of oscillatory processes in the behavior of biosocial systems]. Psikhologicheskiy zhurnal, 36 (6), 76-87. Retrieved from http://www.ipras.ru/cntnt/rus/ institut_p/psihologic/psihologiy.html.

Grobstein, C. (1968). Strategii zhizni [The strategy of life]. Moscow: Mir.

Haxby, J., \& Gobbini, M. (2011). Distributed neural systems for face perception. In A. Calder, G. Rhodes, M. Johnson, \& J. V. Haxby (Eds.), Oxford handbook of face perception (pp. 93-110). New York: Oxford University Press. https://doi.org/10.1093/ oxfordhb/9780199559053.013.0006

Hedrick, F. (2003). Genetika populyatsiy [Population genetics]. Moscow: Tekhnosfera.

Izard, K.E. (2011). Psikhologiya emotsiy [The psychology of emotions]. Saint Petersburg: Piter.

Izmailov, Ch.A., Korshunova, S.G., \& Sokolov, E.N. (2003). Semanticheskiy komponent vyzvannogo potentsiala razlicheniya [The semantic component of the evoked potential to differences]. In Sovremennye napravleniya mezhdistsiplinarnykh issledovaniy (pp. 295-308). Moscow: IP RAN.

Kandel, E.R. (2016). Vek samopoznaniya: Poisk nessonatelnogo $v$ iskusstve i nauke s nachala XX veka do nashikh dney [The age of insight: The quest to understand the unconscious in art, mind, and brain, from Vienna 1900 to the present]. Moscow: Act: Corpus.

Kanner, L. (1943). Autistic disturbances of affective contact. Nervous Child, 2, 217-250. Retrieved from http://simonsfoundation.s3.amazonaws.com/share/071207-leo-kanner-autistic-affective-contact.pdf.

Kanwisher, N., \& Dilks, D. (2013). The functional organization of the ventral visual pathway in humans. In L. Chalupa \& J. Werner (Eds.) The new visual neurosciences (pp. 733-746). Cambridge, MA: MIT Press.

Klug, W., \& Cummings, M. (2009). Osnovy genetiki [Concepts of genetics]. Moscow: Tekhnosfera.

Kropotkin, P.A. (2007). Vzaimnaya pomoshch kak factor evolyutsii [Mutual aid as a factor in evolution]. Moscow: Redaktsiya zhurnala Samoobrazovanie.

Lebedinskiy, V.V. (1985). Narusheniya psikhicheskogo razvitiya u detey [Impaired mental development in children]. Moscow: Lomonosov MGU.

Lebon, G. (1998). Psikhologiya tolpy [The psychology of the crowd]. Moscow: IP RAN.

Lorenz, K. (1998). Oborotnaya storona zerkala [Behind the mirror]. Moscow: Respublika.

Lorenz, K. (2003). Agressiya (tak nazyvaemoe "zlo") [Aggression (the so-called "evil")]. Moscow: Progress, UNIVERS.

Lotman, Yu.M. (2015). Vnutri myslyashchikh mirov [Inside conceiving worlds]. Saint Petersburg: Azbuka, Azbuka-Attikus.

Luhmann, N. (1995). Chto takoe kommunikatsiya? [What is communication?]. Sotsiologicheskiy zhurnal, 3, 114-124. Retrieved from http://jour.isras.ru/index.php/socjour/index.

Markov, A.V. (2010). Rozhdenie slozhnosti [The birth of complexity]. Moscow: Astrel: CORPUS.

Morris, D. (1962). The biology of art: A study of the picture-making behavior of great apes and its relationship to human art. London: Cox \& Wyman Ltd.

Nikolskaya. O.S. (2000). Affektivnaya sfera cheloveka: vzglyad skvoz prizmu detskogo autizma [The affective sphere of the person: Through the prism of childhood autism]. Moscow: Tsentr lechebnoy pedagogiki. 
Palmer, J.A., \& Palmer, L.K. (2002). Evolutionary psychology. The ultimate origins of human behavior. Boston: Allyn \& Bacon Company.

Pavlov, I.P. (1951). Polnoe sobranie sochineniy [Complete works]. Moscow-Leningrad: AN SSSR.

Perrett, D.I., Rolls, E.T., \& Caan, W. (1982). Visual neurons responsive to faces in the temporal cortex. Experimental Brain Research, 47, 329-342. https://doi.org/10.1007/BF00239352

Pinker, S. (2013). Substantsiya myshleniya. Yazyk kak okno v chelovecheskuyu prirodu [The stuff of thought. Language as a window into human nature]. Moscow: Librocom.

Ramachandran, V.S. (2006). Rozhdenie razuma [The emerging mind]. Moscow: Olimp-Biznes.

Ridley, M. (2014). Proiskhozhdenie altruizma i dobrodeteli: ot instinktov $k$ sotrudnichestvu [The origins of virtue]. Moscow: Eksmo.

Rizzolatti, J., \& Sinigaglia, K. (2012). Zerkala mozga [Mirrors in the brain]. Moscow: Yazyki slavyanskikh kultur.

Sacks, O. (1985). The man who mistook his wife for a hat. New York: Harper Collins.

Schrödinger, E. (2005). Moy vzglyad na mir [My view of the world]. Moscow: KomKniga.

Sirota, E.L., Shekhter, E.D., \& Edrenkin, I.V. (2011). Semanticheskoe prostranstvo nazvanii emotsii pri autizme [Semantic Space of Emotion Names Associated with Autism]. Psychology. Journal of Higher School of Economics, 8(1), 122-138. Retrived from https://psy-journal. hse.ru/en/2011-8-1/29332327.html

Sokolov, E.N. (2010). Ocherki po psikhofiziologii soznaniya [Essays on the psychophysiology of consciousness]. Moscow: Lomonosov MGU.

Steffenburg, S. (1991). Neuropsychiatric assessment of children with autism: A populationbased study. Developmental Medicine and Child Neurology, 33, 495-511. https://doi. org/10.1111/j.1469-8749.1991.tb14915.x

Von Hildebrandt, D. (1998). Metafizika kommunikatsiy. Issledovanie sushchnosti i tsennosti kommunikatsiy [The metaphysics of communications. Study of the nature and value of communications]. Saint Petersburg: ALETEYYA.

Wilson, E.O. (1975). Sociobiology: The new synthesis. Cambridge, MA: Belknap Press of Harvard University Press.

Wilson, E.O. (2015). Smysl sushchestrovaniya cheloveka [The meaning of human existence]. Moscow: Alpina non-fikshn.

Wing, L. (1981). Language, social and cognitive impairments in autism and severe retardation. Journal of Autism and Developmental Disorders, 11, 39-45. https://doi.org/10.1007/ BF01531339

Zaporozhets, A.V. (1986). Izbrannye psikhologicheskie trudy: $v 2$ tomakh [Selected psychological works: in 2 volumes]. Moscow: Pedagogika.

Zavarzin G.A. (1993). Razvitie mikrobnykh soobshchestv $v$ istorii Zemli [The development of microbial communities in Earth's history]. Sbornik "Problemy doantropogennoy evolyutsii biosfery". Moscow: Nauka, p. 212-222.

Zavarzin G.A. (2003). Evolyutsiya mikrobnikh soobshchestv [Evolution of microbial communities]. In Materialy seminara "Proiskhozhdenie zhivykh sistem", 15-20 August. Retrieved from http://www.bionet.nsc.ru/live/live.php?f=doclad\&p=zavarzin.

Zorina, Z.A., Poletaeva, I.I., \& Reznikova, Zh.I. (1999). Osnovy etologii i genetiki povedeniya [The foundations of ethology and behavior genetics]. Moscow: Lomonosov MGU. 